J. Dairy Sci. 92:117-129

doi:10.3168/jds.2008-1382

(c) American Dairy Science Association, 2009.

\title{
Transcriptome profiling of Streptococcus uberis-induced mastitis reveals fundamental differences between immune gene expression in the mammary gland and in a primary cell culture model
}

\author{
K. M. Swanson, ${ }^{1}$ K. Stelwagen, J. Dobson, H. V. Henderson, S. R. Davis, ${ }^{2}$ V. C. Farr, and K. Singh \\ AgResearch Ltd., Ruakura Research Centre, Private Bag 3123, Hamilton 3240, New Zealand
}

\begin{abstract}
Streptococcus uberis is a prevalent causative organism of mastitis and resides naturally in the environment of the dairy cow making prevention of the disease difficult. A bovine cDNA microarray comprising approximately 22,000 expressed sequence tags was used to evaluate the transcriptional changes that occur in the mammary gland after the onset of clinical Strep. uberis mastitis. Five lactating Friesian heifers were intramammary infused in an uninfected quarter with approximately 1,000 to 1,500 cfu of a wild-type strain of Strep. uberis. Microarray results showed that Strep. uberis mastitis led to the differential expression of more than 2,200 genes by greater than 1.5 -fold compared with noninfected control quarters. The most highly upregulated genes were associated with the immune response, programmed cell death, and oxidative stress. Quantitative real-time reverse transcription $\mathrm{PCR}$ analysis confirmed the increase in mRNA expression of immune-related genes complement component 3, clusterin, IL-8, calgranulin C, IFN- $\gamma$, IL-10, IL-1 $\beta$, IL-6, toll-like receptor-2, tumor necrosis factor- $\alpha$, serum amyloid A3, lactoferrin, LPSbonding protein, and oxidative stress-related genes metallothionein $1 \mathrm{~A}$ and superoxide dimutase 2 . In contrast, a decrease of mRNA levels was observed for the major milk protein genes. Bovine mammary epithelial cells in culture challenged with the same Strep. uberis strain used to induce clinical mastitis in the in vivo animal experiment did not cause a change in the mRNA levels of the immune-related genes. This suggests that the expression of immune-related genes by mammary epithelial cells may be initiated by host factors and not Strep. uberis. However, challenging epithelial cells with different Strep. uberis strains and Staphylococcus aureus resulted in an increase in the mRNA expression of a subset of the immune-related genes measured.
\end{abstract}

Received May 21, 2008.

Accepted September 1, 2008.

${ }^{1}$ Corresponding author: kara.swanson@agresearch.co.nz

${ }^{2}$ Present address: ViaLactia Biosciences (N.Z.) Ltd., Newmarket, Auckland 1031, New Zealand.
In comparison, an Escherichia coli challenge caused an increase in the majority of immune-related genes measured. Results demonstrate the complexity of the bovine mammary gland immune response to an infecting pathogen and indicate that a coordinated response exists between the resident, recruited, and inducible immune factors.

Key words: mastitis, bovine, microarray, Streptococcus uberis

\section{INTRODUCTION}

Bovine mastitis is an inflammation of the mammary gland and is usually a consequence of microbial infection (Jain, 1979). It is a highly prevalent and costly disease for the dairy industry worldwide (Blosser, 1979; DeGraves and Fetrow, 1993). Streptococcus uberis is a major causative agent of IMI in dairy cows both in countries with pasture-based management systems and seasonal calving (Hillerton et al., 1993; McDougall, 2002) and where cattle are housed and have year-round calving (Hillerton et al., 1993; McDougall, 2002). Streptococcus uberis resides naturally in the environment and has been isolated from the soil, races, and feces, in addition to various anatomical regions in the cow (Cullen, 1966; Khan et al., 2003; Lacy-Hulbert et al., 2005). Currently, it is not effectively controlled using existing control methods (Leigh, 1999), with the primary means being through administration of antibiotics after the identification of infection. However, with ongoing international pressure to decrease antibiotic use in agriculture due to its perceived link to increasing antibiotic resistance (Teuber, 2001; Phillips et al., 2004), an understanding of the bovine immune response to mastitis may elucidate alternate avenues of combating this disease.

The immune response associated with mastitis is a very complex biological process and involves resident, recruited, and inducible immune factors (Rainard and Riollet, 2006). The innate immune response is the predominant defense during the early stages of infection and is induced rapidly at the site of infection (Sordillo 
et al., 1997). Distinctive differences in the innate immune response have been reported after the infusion of gram-positive and gram-negative organisms into the mammary gland (Bannerman et al., 2004a,b). Although the systemic and innate immune response for gram-negative organisms appears similar, differences were evident in these responses for 2 prolific mastitiscausing gram-positive pathogens, Staphylococcus aureus and Strep. uberis (Bannerman et al., 2004a,b). These studies highlight the variability of the innate immune response to different pathogens and establish the importance of understanding the mediators involved in the recognition and signaling of invasion by specific pathogens. Understanding of the immune response of the bovine mammary gland during Strep. uberis mastitis is still very rudimentary. However, this broad-spectrum response offers potential avenues of research for increasing the control and prevention of mastitis through the numerous immune and epithelial cell-derived molecules, which respond to the presence of pathogens in the mammary gland (Paape et al., 2000; Bannerman et al., 2004a).

Microarray technology enables the examination of complex interactions between the host and bacterial pathogens (Zheng et al., 2006). It has become a valuable tool in experimental biology, because it enables the simultaneous generation of quantitative data relating to the differential expression of thousands of genes (Schena et al., 1995; Shalon et al., 1996). The identification of genes whose expression is altered in response to bacterial pathogens and the ability to classify these into biologically functional groups aid in the overall understanding of the host response to a specific pathogen (Zheng et al., 2006). The purpose of this study was to analyze the changes in gene expression in vivo in the bovine mammary gland in response to Strep. uberis and to compare this to other significant mastitis pathogens in vitro to identify the specific role of the epithelial cells using a bovine mammary epithelial cell (bMEC) model. The use of microarray technology allowed a comprehensive investigation into the complex transcriptional changes that occur after the onset of clinical Strep. uberis mastitis and subsequent comparative in vitro studies of Strep. uberis and other mastitis pathogens, highlighted differences in the immune response to these pathogens, and improves the overall understanding of this disease.

\section{MATERIALS AND METHODS}

\section{Animals and Sample Collection}

A healthy front and rear quarter of the mammary gland of each of 5 Friesian heifers (mid-late lactation) was infused with approximately 1,000 to $1,500 \mathrm{cfu}$ of a wild-type strain of Strep. uberis (Strep. uberis 233, New Zealand clinical mastitis isolate, nonencapsulated) in $1 \mathrm{~mL}$ of quarter-strength Ringer's solution (Oxoid, Hampshire, UK) immediately after an afternoon milking (Milner et al., 1997). One of these quarters was selected for analysis (Table 1). The strain of Strep. uberis was in the log growth phase, and serial dilution plate counts were performed to enumerate the inoculum before infusion. The Strep. uberis strain used had been previously isolated from a cow with clinical mastitis. The cows were observed for visual signs of clinical mastitis. Animals had no previous episodes of clinical or subclinical mastitis. Quarter milk samples on the day of trial confirmed that the sampled quarters were free from mastitis pathogens and had less than 150,000 cells $/ \mathrm{mL}$. The animals were slaughtered at the Ruakura abattoir (Hamilton, New Zealand) using standard commercial procedures (electrical stunning followed by exsanguination). Mammary alveolar tissue (approximately $30 \mathrm{~g}$ ) was collected from the middle of the upper one-third of one of the Strep. uberis-infused quarters displaying clinical signs of mastitis, specifically clots in the milk, and a control quarter that had the lowest SCC and negative bacteriology data (Table 1). Samples were snap-frozen in liquid nitrogen for subsequent RNA and protein extraction. All procedures were approved by the Ruakura Animal Ethics Committee in accordance with the 1999 Animal Welfare Act of New Zealand. Milk samples were taken for bacteriological examination and SCC to determine infection status 1 $\mathrm{h}$ before tissue sampling (Stelwagen and Lacy-Hulbert, 1996).

\section{Array Preparation}

Bovine cDNA libraries were generated at AgResearch from a variety of tissues from both dairy and beef breeds as described by Singh et al. (2008). Expressed sequence tags (EST) were amplified, and a microarray consisting of 21,378 spots was printed onto poly-L-lysine-coated glass slides using an ESI array robot (ESI, Toronto, Canada) at the University of Otago Genomics Facility (Dunedin, New Zealand) as described by Baird et al. (2004).

\section{Target Preparation and Hybridization}

Labeled cDNA was prepared as described in Singh et al. (2008). Briefly, total RNA from mammary alveolar tissue was extracted using Trizol reagent (Invitrogen, Carlsbad, CA) and purified using an RNeasy kit (Qiagen, Valencia, CA). Ribonucleic acid integrity 
Table 1. Somatic cell count and bacteriology results for individual quarters

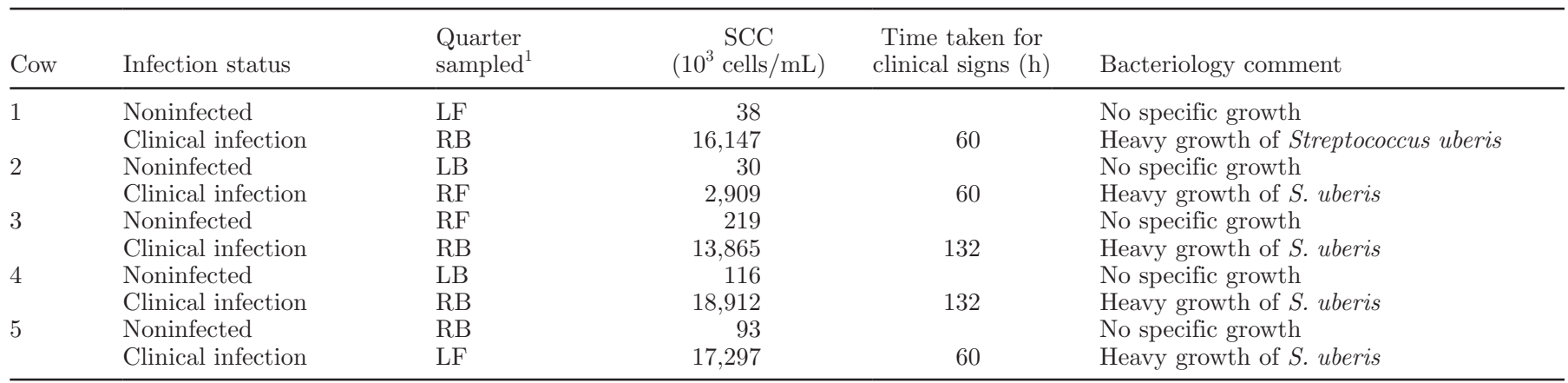

${ }^{1} \mathrm{LF}=$ left front; $\mathrm{LB}=$ left back; $\mathrm{RF}=$ right front; $\mathrm{RB}=$ right back.

was confirmed by denaturing agarose gel electrophoresis and quantified by UV spectrophotometry. Labeled cDNA was produced from $25 \mu \mathrm{g}$ of total RNA by oligo (dT)-primed reverse transcription and incorporation of aminoallyl-deoxyuridine triphosphate, using Moloney murine leukemia virus reverse transcriptase (Ambion Inc., Austin, TX). The amino-modified cDNA was coupled to reactive forms of $\mathrm{Cy} 3$ and $\mathrm{Cy} 5$ dyes using the Ambion amino allyl cDNA labeling kit (Ambion Inc.). The slides were hybridized with the labeled cDNA using ULTRAhyb (Ambion Inc.) as described previously (Baird et al., 2004). A dye swap was incorporated into the experimental design to eliminate bias related to the incorporation of the 2 different dyes. The microarray data were read using a GenePix 4200a Scanner (Axon Instruments Inc., Union City, CA), and the images were analyzed using GenePix Pro 3.0 software (Axon Instruments Inc.), which included automated and manual flagging of bad spots.

\section{Microarray Normalization and Analysis}

The microarray expression data for each slide were normalized following the procedure of Baird et al. (2004) using GenStat (VSN International, Hemel Hempstead, UK). To determine which EST were differentially expressed, the normalized data for each EST from all 10 slides were averaged, correcting for dye reversal, and the $P$-value was reported from a $t$-test. Expressed sequence tags were excluded from further analysis if they had more than 5/10 bad spots. A total of 19,760 EST were selected for further analysis representing 10,337 distinct contiguous sequences (contig), of which 6,812 were represented only once. Of the selected EST, 16,409 matched to entries in the human RefSeq database, and these represented 8,216 different contig. The 3,351 EST with no RefSeq matches represented 2,121 different contig. These remaining EST were sorted based on the mean normalized (or corrected) log ratio.

\section{Microarray Data Interpretation}

To annotate the microarrays, all the EST sequences, including those publicly deposited in National Center for Biotechnology Information (http://www.ncbi.nlm. nih.gov/), were assembled into contig using the DNA assembly program CAP3 (Huang and Madan, 1999) after an initial clustering step using BLAST analysis (http://www.ncbi.nlm.nih.gov/blast/Blast.cgi; Altschul et al., 1990). The corresponding human RefSeq (RefSeq release as at September 15, 2006) for each contig represented on the microarray array was obtained using $\operatorname{BLAST}\left(\mathrm{E}<1 \times 10^{-10}\right)$. In cases in which the contig matched more than 1 transcript variant of a gene, the top hit was used. Expressed sequence tags were considered differentially expressed if they were up- or downregulated by $\geq 1.5$-fold or $\leq-1.5$-fold, respectively $(P<$ 0.05), based on their C_logRatio. Contigs represented by multiple EST were considered as differentially expressed if at least one-third of the EST were up- or downregulated by $\geq 1.5$-fold $(P<0.05)$ and if the average of the C_logRatio for all EST equated to differential expression of $\geq 1.5$-fold. Ontological classification and further annotation of the genes encoded by the differentially expressed EST were performed using the Database for Annotation, Visualization and Integrated Discovery (DAVID; Dennis et al., 2003). The human RefSeq representing differentially expressed EST were submitted to DAVID with a background list including all human RefSeq $\left(\mathrm{E}<1 \times 10^{-10}\right)$ on the microarray $(P<0.05)$. The Fisher's exact $P$-value was used to measure the gene enrichment and identifies EST that are specifically regulated after the onset of Strep. uberis infection. Statistically significant gene ontology terms $(P<0.05)$ are reported.

\section{Quantitative Real-Time Reverse Transcription PCR Analysis}

First-strand cDNA was generated from RNA samples using the SuperScript III Reverse Transcriptase First- 
Strand Synthesis System kit (Invitrogen; Singh et al., 2008). Before use as templates in PCR amplification, cDNA samples were diluted 5 -fold in $10 \mathrm{~m} M$ Tris $\mathrm{pH}$ 8.0. The cDNA samples were assayed on 96-well optical plates (Applied Biosystems, Foster City, CA) in duplicate using an ABI PRISM 7700 System (Applied Biosystems). Each plate included an assay for an endogenous control gene (ubiquitin) as well as primers for the target gene of interest. Primer sequences for complement component 3 (C3), clusterin, cluster of differentiation (CD) 55 molecule (decay accelerating factor for complement, DAF), chemokine (C-X-C motif) ligand 1 (CXCL1), chemokine (C-X-C motif) ligand 2 (CXCL2), IL-13, IL-6, IL-8, IL-10, calgranulin C (S100A12), IFN- $\gamma$, LPS-binding protein (LBP), serum amyloid A3 (SAA3), transforming growth factor- $\beta$, toll-like receptor 2 (TLR2), and tumor necrosis factor- $\alpha$ (TNF- $\alpha$ ) were designed from published nucleic acid sequences using Primer 3 software (Rozen and Skaletsky, 2000) and are described in Supplementary Table 1 (http://jds.fass.org/content/vol92/issue1/). Primer sequences for $\alpha-\mathrm{LA}, \beta-\mathrm{LG}, \alpha \mathrm{S} 1-\mathrm{CN}, \beta-\mathrm{CN}$, $\kappa$-CN, lactoferrin, lingual antimicrobial peptide (LAP), superoxide dismutase 2 (SOD2), metallothionein 1A, and ubiquitin are described previously (Singh et al., 2008). Each quantitative reaction contained $7.5 \mu \mathrm{L}$ of SYBR Green Master Mix (Applied Biosystems), $1 \mu \mathrm{L}$ of cDNA template, and $300 \mathrm{n} M$ of each primer pair. An initial denaturation step of $95^{\circ} \mathrm{C}$ for 10 min preceded 40 cycles of $95^{\circ} \mathrm{C}$ for $15 \mathrm{~s}, 56$ to $62^{\circ} \mathrm{C}$ for $30 \mathrm{~s}, 72^{\circ} \mathrm{C}$ for $30 \mathrm{~s}$, and $78^{\circ} \mathrm{C}$ for $10 \mathrm{~s}$. A dissociation curve of the amplified products was acquired after the 40 cycles by a further run of $95^{\circ} \mathrm{C}$ for $15 \mathrm{~s}$, then $60^{\circ} \mathrm{C}$ for $15 \mathrm{~s}$ followed by a slow ramp up to $95^{\circ} \mathrm{C}$ for $15 \mathrm{~s}$. The PCR products were verified by sequencing (Waikato DNA Sequencing Facility, Hamilton, New Zealand). Relative quantification of gene expression was performed using the standard curve method (Applied Biosystems). Briefly, standard curves of serial dilutions of PCR products generated from each primer pair were used to calculate the relative amounts of each gene in the cDNA samples. The amount of target gene in each sample was normalized to the endogenous control gene (ubiquitin) and the resulting values were base-10 logarithm-transformed. The levels of mRNA were then backtransformed and expressed as the mean fold change \pm SEM relative to the noninfected mean. Differences between the infected and noninfected means were analyzed by ANOVA of the log-transformed data in GenStat, with the LSD between means calculated $(P<0.1, P<0.05, P<$ $0.01, P<0.001)$.

\section{Cell Culture}

Streptococcus uberis 233 and 262 (New Zealand clinical mastitis isolate, encapsulated), Escherichia coli (ATCC25922), and Staph. aureus (ATCC25923) were collected by centrifugation $(10,000 \times g, 30 \mathrm{~min})$ after overnight growth in Todd Hewitt broth, Luria-Bertani broth, and tryptic soy broth, respectively. Bacterial concentrations were defined by plating serial dilutions. The bacterial cells were washed in PBS, resuspended at a concentration of $1 \times 10^{10} \mathrm{cfu} / \mathrm{mL}$ in $1 \times$ PBS, $10 \%$ glycerol, and stored at $-80^{\circ} \mathrm{C}$. Before use, bacterial cells were heat-killed at $65^{\circ} \mathrm{C}$ for $30 \mathrm{~min}$, and inactivation efficiency was verified on blood agar plates. Cells were resuspended at the required concentration in cell culture media. Plating of dilution series was used to verify cell counts.

Primary cultures of bMEC were isolated from a slaughtered third trimester pregnant cow. Approximately $100 \mathrm{~g}$ of alveolar tissue was removed immediately after slaughter and transported back to the laboratory in Hanks' balanced salt solution (HBSS) containing antibiotic-antimycotic (Invitrogen). Tissue samples were rinsed several times in HBSS and were then cut into $1-\mathrm{cm}^{2}$ pieces, removing fat and connective tissue. These pieces were then injected with digest mixture [HBSS with $0.4 \%$ BSA (wt/vol), $2 \mathrm{~m} M$ glutamine, MEM AA solution (Invitrogen), $5.5 \mathrm{~m} M$ glucose, 1.2 $\mathrm{mg} / \mathrm{mL}$ of collagenase IV (Worthington Biochemical Corp., Lakewood, NJ), $0.02 \mathrm{mg} / \mathrm{mL}$ of DNase I, 0.5 $\mathrm{mg} / \mathrm{mL}$ of hyaluronidase (Sigma, St. Louis, MO), $1 \mu \mathrm{g} /$ $\mathrm{mL}$ of cortisol, $5 \mu \mathrm{g} / \mathrm{mL}$ of insulin, and antibiotic-antimycotic (Invitrogen)]. Approximately $50 \mathrm{~g}$ of tissue was placed into $500-\mathrm{mL}$ conical flasks containing $250 \mathrm{~mL}$ of digest mixture, and digestion proceeded for $2 \mathrm{~h}$ in an orbital shaker $\left(37^{\circ} \mathrm{C} ; 110 \mathrm{rpm}\right)$. After the digestion period, cellular debris and single cells were removed by centrifugation $(80 \times g ; 5 \mathrm{~min})$. The remaining tissue samples were minced with opposing scalpel blades and digested for a further $3 \mathrm{~h}$. Cells were then filtered through $150-\mu \mathrm{m}$ mesh and centrifuged $(100 \times g ; 10$ min). Cells were washed in HBSS before fractionation on a Percoll (Sigma) gradient. Epithelial cells banded at 1.03 to $1.05 \mathrm{~g} / \mathrm{mL}$ fractions after centrifugation at $800 \times g$ for $20 \mathrm{~min}$. The resulting cells were washed in HBSS and cryopreserved at a concentration of 20 $\times 10^{6}$ cells $/ \mathrm{mL}$ in $90 \%$ fetal calf serum, $10 \%$ dimethyl sulfoxide.

Primary cell aliquots were thawed and grown to confluence in $10-\mathrm{cm}^{2}$ plates in a composite Medium 199/ Hams F12 medium (Invitrogen) supplemented with 45 $\mathrm{m} M$ sodium bicarbonate, $0.4 \mathrm{~m} M$ sodium acetate, 10 
$\mathrm{m} M$ HEPES, $5 \%$ fetal calf serum, $5 \%$ horse serum, 5 $\mu \mathrm{g} / \mathrm{mL}$ of insulin, and $1 \mu \mathrm{g} / \mathrm{mL}$ of cortisol. Cells were then trypsinized and split into two 6 -well plates. The cells were cultured until confluence before subsequent addition of fresh media with or without (control) heatkilled bacteria at final concentrations of $1 \times 10^{9} \mathrm{cfu} / \mathrm{mL}$, representing a multiplicity of infection of approximately 1,000. Each treatment was performed in triplicate, and the experiment was repeated. After incubation for $12 \mathrm{~h}$, the cells were washed with PBS and harvested by trypsination using trypLE (Invitrogen) for $10 \mathrm{~min}$. Total RNA was extracted from the cells and cDNA generated for use in quantitative real-time reverse transcription PCR (qRT-PCR) as described above. The differences between means and fold changes relative to the control were analyzed as described above.

\section{RESULTS}

The microarray analysis examined gene expression changes in the alveolar mammary tissue from quarters showing clinical signs of mastitis induced by infusion with Strep. uberis compared with healthy noninfected quarters from the same cows. A significance threshold of $P<0.05$, with at least 1.5 -fold change, was used in all comparisons. There were 1,083 different genes upregulated (including 326 with no human RefSeq: GenBank accession number) and 1,212 genes downregulated (including 239 with no human RefSeq: GenBank accession number) in Strep. uberis-infected mammary alveolar tissue compared with the noninfected tissue. Of these genes, there were 15 that were upregulated and only 1 that was downregulated by $>5$-fold in the infected tissue compared with the noninfected tissue (Supplementary Tables 2 and 3; http://jds.fass.org/content/ vol92/issue1/). These highly upregulated genes include the antiapoptotic SON DNA-binding protein (7.26fold); the calcium-binding protein, S100A12 (7.26-fold), which is involved in the inflammatory response; and the acute-phase protein, SAA3 (6.91-fold). The complete lists of differentially expressed genes $(P<0.05$, with at least a 1.5-fold change) with human RefSeq (E $<1 \times 10^{-10}$ ) and DAVID classifications are provided in Supplementary Tables 2 and 3 (http://jds.fass.org/ content/vol92/issue1/).

The differentially expressed genes had many different DAVID classifications. The upregulated genes with the greatest fold changes had functions predominantly associated with a response to the presence of Strep. uberis, such as response to biotic stimulus, defense response, immune response, response to stimulus, and response to pest, pathogen, or parasite. Genes involved in homeostasis were also significantly upregulated in the Strep. uberis-infected samples compared with non- infected samples (Table 2; Supplementary Table 2; http://jds.fass.org/content/vol92/issue1/). In contrast, the downregulated genes had functions pertaining to metabolism, development, and DNA damage (Table 3; Supplementary Table 3; http://jds.fass.org/content/ vol92/issue1/).

Genes with functions related to the response to Strep. uberis that were upregulated were more specifically classified to reactive oxygen species, acute-phase response, inflammatory response, immune response, and complement (Table 2). The genes represented by these categories included induced inflammatory genes, such as chemokines [chemokine (C-C motif) ligand 21], acute-phase proteins (SAA3, haptoglobin, and LBP), the LPS-signaling receptor (CD14 antigen), cytokine-associated genes (IL-10 receptor and IL-6 signal transducer), and reactive oxygen species (SOD2), in addition to the stress-responsive transcription factor signal transducer and activator of transcription-3 (STAT3) and antimicrobial milk proteins (such as lactoferrin; Table 2). Genes with functions related to cell proliferation and programmed cell death were also induced after a Strep. uberis infection with both apoptotic (dual-specificity phosphatase 6, growth arrest and DNA damage-inducible $\beta$, B-cell chronic lymphocytic leukemia/lymphoma 10) and antiapoptotic (SON DNA-binding protein) genes being induced. The genes represented in the cell proliferation category were primarily associated with the negative regulation of cell proliferation. The genes that were downregulated had functions related to lipid metabolism, vesicle-mediated transport, and cellular responses and cell death, including complement components $(\mathrm{C} 1 \mathrm{Q}, \mathrm{C} 2, \mathrm{C} 6)$, cytokines (IL18), and transcription factors (signal transducer and activator of transcription 5A) and apoptotic serum glucocorticoid kinase (Table 3).

Eleven immune-associated genes that were differentially expressed by microarray analysis were also assessed by qRT-PCR (Figure 1a). Similar to the microarray analysis, C3, which was represented by 4 EST on the microarray, was significantly increased by 2.4fold after Strep. uberis infection compared with noninfected samples. Clusterin and DAF are also associated with the complement cascade. The microarray analysis showed both clusterin (8 EST) and DAF (1 EST) had an increase in expression $(P<0.05)$ in infected tissue by 1.7 - and 1.3-fold, respectively, compared with noninfected samples. However, qRT-PCR analysis showed that clusterin tended to be increased $(P<0.1)$ by 3.4 -fold and DAF mRNA levels were unchanged in mastitic samples compared with noninfected samples. The chemokines, CXCL1 (1 EST) and IL-8 (1 EST) were downregulated $(P<0.05)$ in infected tissues by 1.8- and 1.5-fold, respectively, compared with nonin- 
Table 2. Genes induced in Streptococcus uberis-infected tissue selected and identified to be of interest on the basis of their gene ontology terms

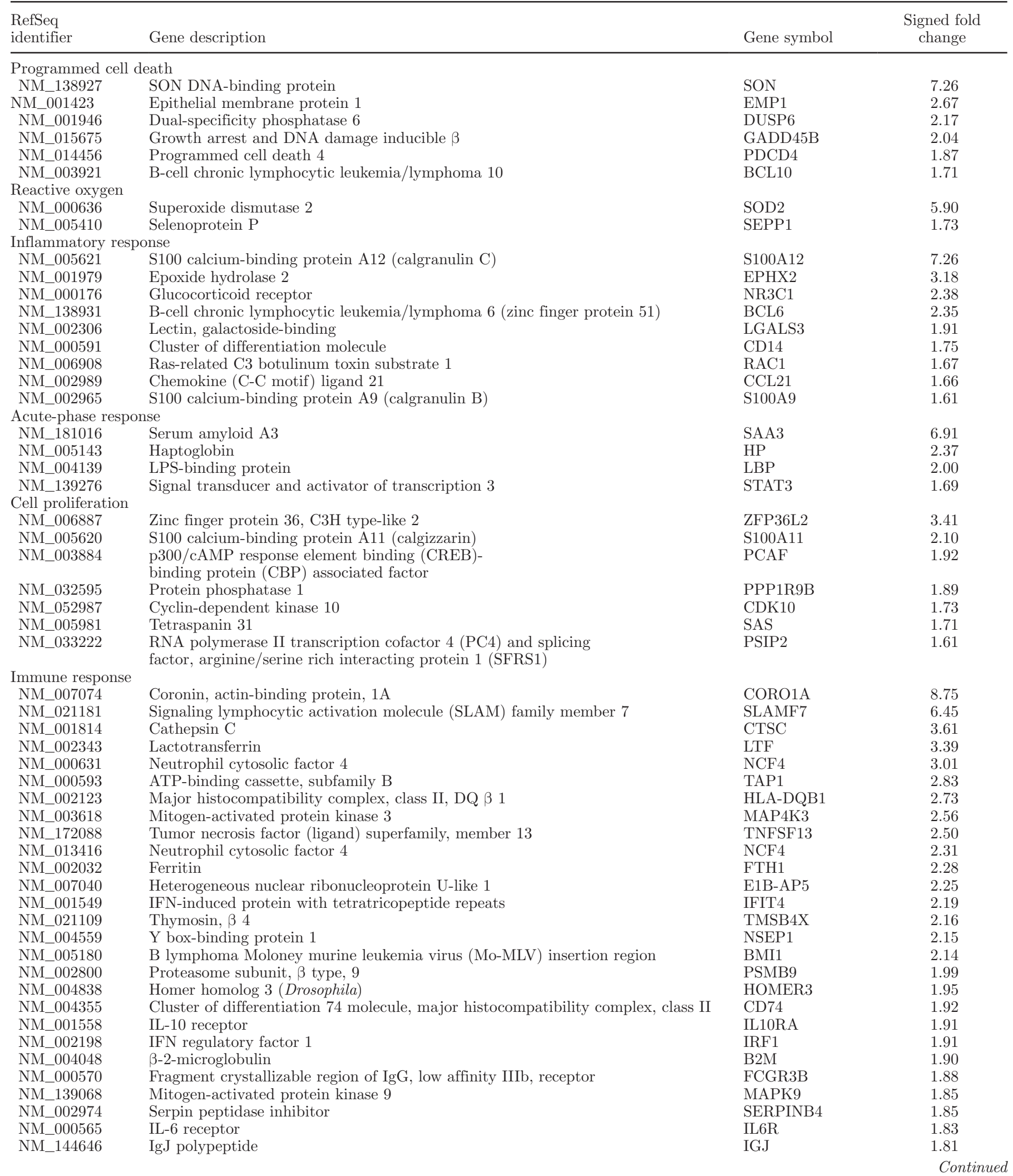


Table 2 (Continued). Genes induced in Streptococcus uberis-infected tissue selected and identified to be of interest on the basis of their gene ontology terms

\begin{tabular}{|c|c|c|c|}
\hline $\begin{array}{l}\text { RefSeq } \\
\text { identifier }\end{array}$ & Gene description & Gene symbol & $\begin{array}{l}\text { Signed fold } \\
\text { change }\end{array}$ \\
\hline NM_002177 & Omega 1 & IFNW1 & 1.80 \\
\hline NM_001560 & IL-13 receptor & IL13RA1 & 1.75 \\
\hline NM_019111 & Major histocompatibility complex, class II, DR $\alpha$ & HLA-DRA & 1.73 \\
\hline NM_002184 & IL-6 signal transducer & IL6ST & 1.73 \\
\hline NM_006016 & Cluster of differentiation 164 molecule, sialomucin & CD164 & 1.72 \\
\hline NM_030781 & Collectin subfamily member 12 & COLEC12 & 1.64 \\
\hline NM_000377 & Wiskott-Aldrich syndrome (eczema-thrombocytopenia) & WAS & 1.62 \\
\hline NM_005615 & Ribonuclease, RNase A family, k6 & RNASE6 & 1.61 \\
\hline \multicolumn{4}{|c|}{ 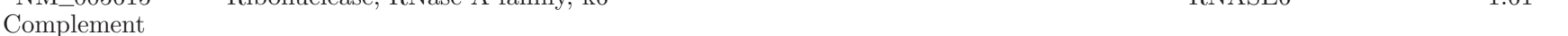 } \\
\hline NM_000064 & Complement component 3 & C3 & 2.36 \\
\hline NM_001710 & Complement factor B & $\mathrm{BF}$ & 1.95 \\
\hline NM_000574 & Cluster of differentiation 55 molecule, decay-accelerating factor for complement & DAF & 1.64 \\
\hline
\end{tabular}

fected tissues by microarray analysis. In contrast, qRTPCR analysis showed that CXCL1 mRNA levels were unchanged, although IL-8 was increased $(P<0.05)$ by 7.9-fold in infected tissue. Microarray analysis showed S100A12 was one of the most highly upregulated $(P<$ 0.05 ) in Strep. uberis-infected tissue by 7.3 -fold, and qRT-PCR analysis showed a dramatic increase, by over 20 -fold compared with noninfected samples. The microarray analysis showed an increase in genes involved in the acute-phase response and oxidative stress (Table 2 ). The average fold change for EST for SAA3 and LBP was 7.6- and 2.0-fold, respectively. In comparison, qRT-PCR analysis showed an increase in SAA3 mRNA levels by 55 -fold and for LBP mRNA levels by 13 -fold. The oxidative stress genes metallothionein and SOD2 were upregulated by 9.4 - and 2.8-fold by microarray analysis and 4.6- and 11.7-fold by qRT-PCR analysis. Lactoferrin, a milk protein with known antimicrobial activity, was upregulated by 3.4-fold (22 EST) on the microarray and 6.5 -fold by qRT-PCR analysis.

Six different cytokines not represented on the microarray were also analyzed by qRT-PCR. Interleukin$1 \beta$, IL-6, and IL-10 were all shown to be more abundant in Strep. uberis-infected tissue, by $15.9-(P<0.05)$, 6.0- $(P<0.05)$, and 3.9-fold $(P<0.1)$, respectively (Figure 1b). The mRNA expression for TLR2, TNF- $\alpha$, and IFN- $\gamma$ also increased by $3.0-(P<0.05), 3.4-(P$ $<0.05)$, and 2.4 -fold $(P<0.1)$, respectively, in Strep. uberis-infected tissue (Figure 1b). Transforming growth factor- $\beta$ and CXCL2 mRNA levels were the same in infected and noninfected samples.

The microarray analysis showed that the milk protein genes were downregulated after a Strep. uberis infection. The average downregulated fold change for the EST for $\alpha \mathrm{S} 1-\mathrm{CN}$ was 1.4-fold (21 EST), $\alpha$-LA was 1.6 -fold (6 EST), $\beta$-LG was 1.3-fold (9 EST), $\beta$-CN was 1.5-fold (12 EST), and $\kappa$-CN was 1.2-fold (8 EST). In comparison, qRT-PCR analysis showed that mRNA levels for $\alpha \mathrm{S} 1-\mathrm{CN}, \alpha-\mathrm{LA}, \beta-\mathrm{LG}, \beta-\mathrm{CN}$, and $\kappa-\mathrm{CN}$ were downregulated by 2.3-, 3.5-, 2.1-, 2.0-, and 1.6-fold, respectively, in Strep. uberis-infected compared with noninfected tissue (Figure 1c).

To further investigate the immune response induced by Strep. uberis, changes in mRNA levels of 9 selected immune-associated genes (C3, clusterin, IL-1 $\beta$, IL-6, IL-8, LAP, SAA3, S100A12, TLR2) were measured in bMEC after incubation with heat-killed bacterial cells (Figure 2). Interestingly, Strep . uberis 233 did not induce changes in expression of any of the genes in bMEC. In contrast, $E$. coli treatment induced a significant increase in expression of all of the genes in the epithelial cells, with the exception of clusterin (Figure 2). Challenging bMEC with an encapsulated strain of Strep. uberis (strain 262, a clinical isolate from a New Zealand farm), unlike Strep. uberis 233, caused a significant $(P<0.05)$ increase in expression of C3 (2.1-fold), SAA3 (4.8-fold), and IL-1 $\beta$ (2.5-fold). The expression of these 3 genes, in addition to TLR2, was also increased $(P<0.05)$ 2.1-, 8.5-, 5.3-, and 1.7-fold, respectively, after incubation of bMEC with Staph. aureus. This increase was more than for Strep. uberis 262 but less than that observed for $E$. coli $(P<0.05)$. No change in expression was observed for clusterin for any of the bacterial stimuli.

\section{DISCUSSION}

This study has used microarray analysis to examine gene expression profiles associated with the response to Strep. uberis infections in the bovine mammary gland. In addition, immune responses to bacterial infection in the mammary gland (in vivo) and bMEC (in vitro) were compared by qRT-PCR. Streptococcus uberis infection 
Table 3. Genes downregulated in infected tissue selected and identified to be of interest on the basis of their gene ontology terms

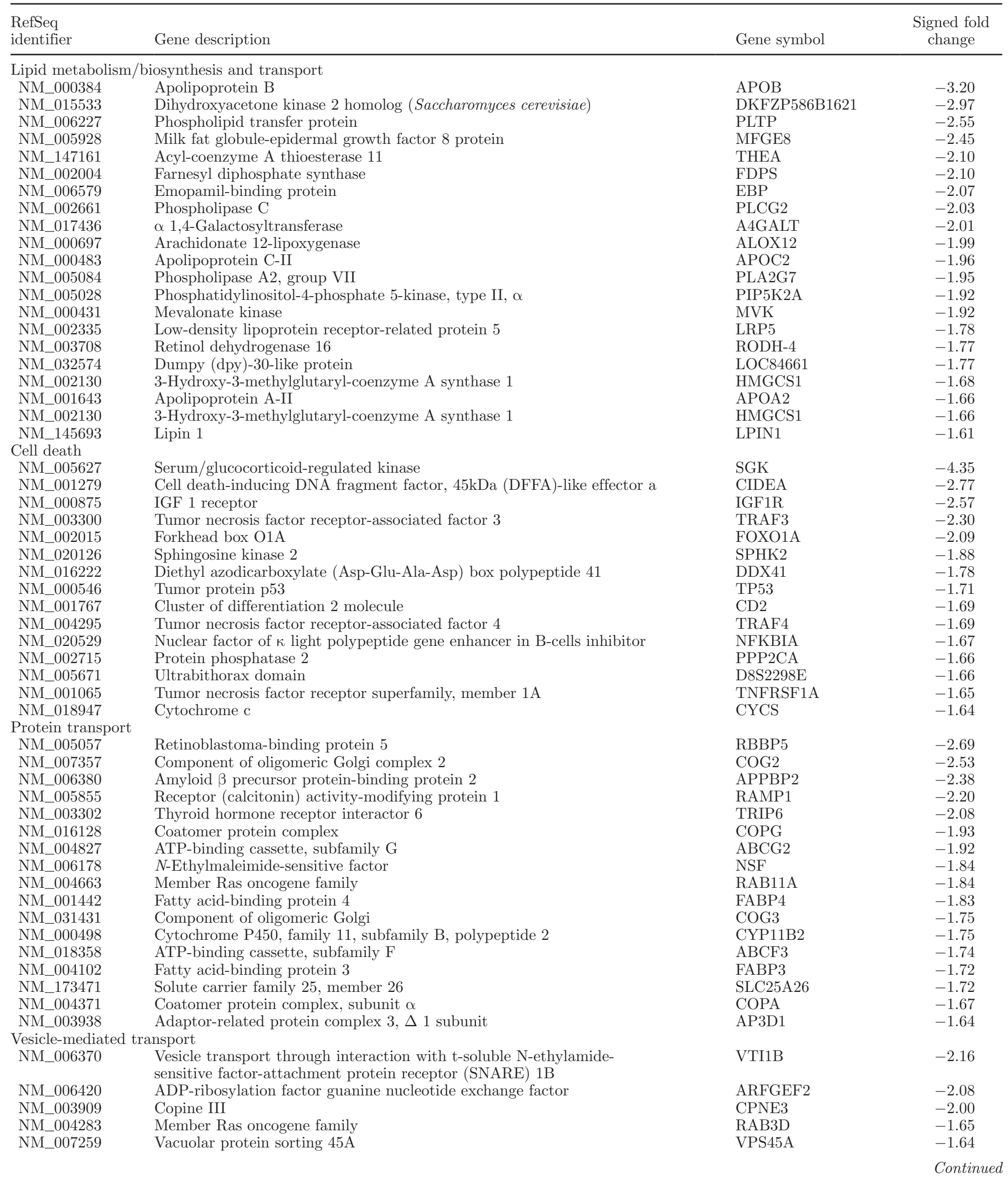


Table 3 (Continued). Genes downregulated in infected tissue selected and identified to be of interest on the basis of their gene ontology terms

\begin{tabular}{|c|c|c|c|}
\hline $\begin{array}{l}\text { RefSeq } \\
\text { identifier }\end{array}$ & Gene description & Gene symbol & $\begin{array}{l}\text { Signed fold } \\
\text { change }\end{array}$ \\
\hline \multicolumn{4}{|l|}{ Signaling } \\
\hline NM_006988 & $\begin{array}{l}\text { A disintegrin and metalloprotease (ADAM) } \\
\text { metallopeptidase with thrombospondin type } 1\end{array}$ & ADAMTS1 & -3.12 \\
\hline NM_006852 & Tousled-like kinase 2 & TLK2 & -2.69 \\
\hline NM_004180 & $\begin{array}{l}\text { Tumor necrosis factor receptor-associated factor family } \\
\text { member-associated nuclear factor } \kappa \mathrm{B} \text { activator }\end{array}$ & TANK & -2.08 \\
\hline NM_000631 & Neutrophil cytosolic factor 4 & NCF4 & -2.17 \\
\hline NM_001562 & IL-18 & IL18 & -1.79 \\
\hline NM_007146 & Zinc finger protein 161 & ZNF161 & -1.79 \\
\hline NM_015991 & Complement component 1 , q subcomponent & $\mathrm{C} 1 \mathrm{Q}$ & -1.74 \\
\hline NM_003152 & Signal transducer and activator of transcription $5 \mathrm{~A}$ & STAT5A & -1.68 \\
\hline NM_000065 & Complement component 6 & $\mathrm{C} 6$ & -1.67 \\
\hline
\end{tabular}

was associated with the differential expression of over 2,200 genes by $>1.5$-fold. Many of the genes with the greatest changes in expression had functions related to immune responses, demonstrating a clear upregulation of immune-associated genes after the onset of Strep. uberis-induced clinical mastitis. Utilization of bMEC cultures for analyzing immune gene regulation has demonstrated the complexity of the immune response of epithelial cells to different types and strains of bacterial infections.

Marked induction of genes encoding the acute-phase proteins SAA3, haptoglobin, and LBP were observed by microarray analysis or qRT-PCR analysis, or both, in Strep. uberis-infected tissue. Increased concentrations of SAA3 and haptoglobin and LBP have previously been reported in milk and serum, respectively, after a Strep. uberis infection (Pedersen et al., 2003; Bannerman et al., 2004a). In addition, LAP (a member of the major antimicrobial peptide family of defensins) is also increased in Strep. uberis-infected tissue (Swanson et al., 2004). Furthermore, the expression of LAP and SAA3 is increased after the infusion of LPS (the principal immunostimulatory molecule of the cell wall of gram-negative bacteria) in teat canals and by challenging primary bMEC in culture with LPS (Wellnitz and Kerr, 2004) and sonicated E. coli extracts (Stockum et al., 2008). Although LBP has primarily been associated with gram-negative bacterial infections, it has been demonstrated that LBP can also bind lipoteichoic acid, a component of the gram-positive bacterial cell wall (Schroder et al., 2003). Moreover, the LBP response to gram-positive bacteria was found to involve CD14, with this pathway dependent on TLR2 (Schroder et al., 2003). In the present study, the CD14 molecule was also found by microarray analysis to be upregulated in Strep. uberis-infected tissue, and TLR2 was shown to increase significantly by qRT-PCR analysis. These observations suggest that the acute-phase proteins have a role in the immune response to Strep. uberis mastitis. Furthermore, the expression of a SAA3 homolog by bMEC (Molenaar et al., 2000) suggests at least some of these acute-phase proteins are part of a local inflammatory response.

The induction of apoptosis by bacterial pathogens is a well-established cellular process (Weinrauch and Zychlinsky, 1999). This microarray analysis demonstrated that genes associated with both apoptotic and antiapoptotic genes were upregulated after the onset of Strep. uberis mastitis. There is a loss of milk yield associated with mastitis, and this was further demonstrated in the present study by a downregulation in milk protein genes. This loss in milk yield could also be attributed to the loss of bMEC during Strep. uberis mastitis (Singh et al., 2006). This has also previously been demonstrated in both Staph. aureus and E. coli mastitis (Bayles et al., 1998; Long et al., 2001). The transcription factor, STAT3, was upregulated in the Strep. uberis-infected tissue on the microarray. In addition to being a mediator of the acute-phase response, STAT3 is also an essential mediator of apoptosis in the mouse mammary gland (Chapman et al., 1999; Humphreys et al., 2002). In agreement, STAT3 is activated during Strep. uberis-induced mastitis and is associated with an increase in bMEC apoptosis (Singh et al., 


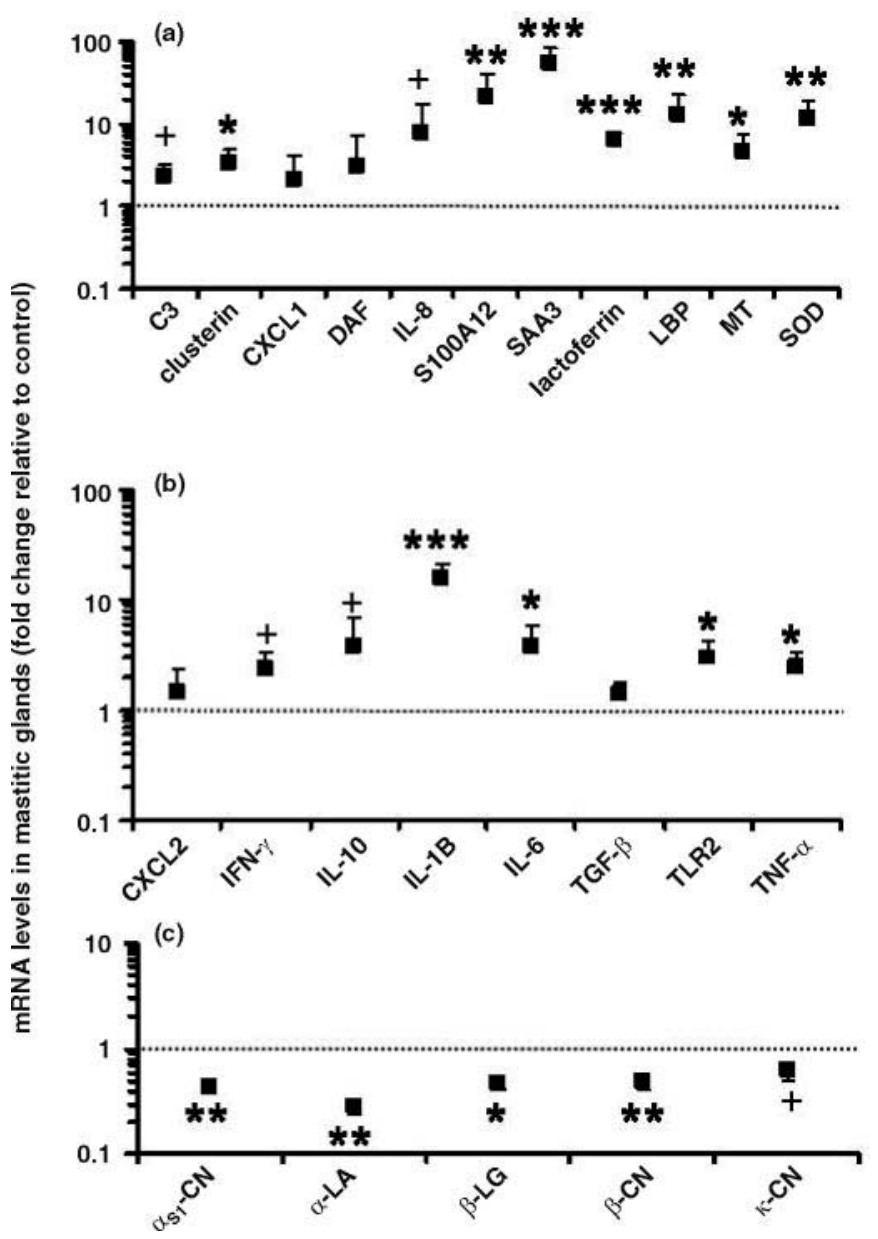

Figure 1. Quantitative PCR analysis of selected genes showing the fold change in Streptococcus uberis-infected tissue. $\left({ }^{+} P<0.1 ;{ }^{*} P\right.$ $<0.05$; ${ }^{* *} P<0.01 ; * * * P<0.001$ ). (a) Immune-associated genes represented on the microarray; (b) Immune-associated genes not present on the microarray; (c) Milk protein genes. Error bars denote SEM. C3 = complement component 3; CXCL1 = chemokine $(\mathrm{C}-\mathrm{X}-\mathrm{C}$ motif) ligand $1 ; \mathrm{DAF}=$ decay-accelerating factor for complement; S100A12 = calgranulin C; SAA3 = serum amyloid A3; LBP = LPS binding protein; $\mathrm{MT}=$ metallothionein; $\mathrm{SOD}=$ superoxide dismutase; CXCL2 = chemokine $(\mathrm{C}-\mathrm{X}-\mathrm{C}$ motif) ligand 2 ; TGF- $\beta=$ transforming growth factor- $\beta$; TLR $2=$ toll-like receptor $2 ; \mathrm{TNF}-\alpha=$ tumor necrosis factor- $\alpha$.

2006). Although mastitis induced by E. coli resulted in increased bMEC apoptosis, an increase in genes associated with cell proliferation was also observed and may play a role in the tissue repair mechanism (Long et al., 2001; Capuco et al., 2003). In the present study, the upregulation of antioxidants such as SOD2, selenoprotein $\mathrm{P}$, and metallothionein also demonstrates a mechanism to limit tissue damage by phagocytosing polymorphonuclear neutrophil granulocytes, which actively release toxic oxygen radicals that not only kill the bacteria but also damage the host cells (Ward, 1983; Paape et al., 2003). Furthermore, the glycoprotein clusterin was increased in Strep. uberis-infected tissue. Studies in vitro have demonstrated that clusterin is induced by reactive oxygen species (Viard et al., 1999). Clusterin has recently been shown to inhibit apoptosis (Zhang et al., 2005). This suggests that along with the proapoptotic and damage repair mechanism genes, there are also genes that may help regulate the process of apoptosis. Furthermore, the processes involving mastitisinduced apoptosis show similarity to those with normal mammary involution-induced apoptosis (Singh et al., 2008).

Cytokines mediate several aspects of the innate immune response including immune cell recruitment, activation, differentiation, and downregulation (Bannerman et al., 2004a). As was found in previous studies investigating the immune response to Strep. uberis in milk (Bannerman et al., 2004a), the cytokines in this study, IL-1 $\beta$, IL-8, IL-10, TNF- $\alpha$, and IFN- $\gamma$, were all shown by qRT-PCR analysis to significantly increase in Strep. uberis-infected tissue. The chemokines CXCL1 and CXCL2 were upregulated in LPS-induced mastitis in a murine epithelial cell line (Zheng et al., 2006). However, significant increases in their expression in Strep. uberis-infected tissue were not observed in this study. Both IL-8 and CXCL1 were demonstrated to be downregulated in Strep. uberis-infected tissue by microarray analysis. However, both of these genes were represented by only $1 \mathrm{EST}$ on the microarray, further highlighting the important application of the microarray as a discovery tool rather than of quantitative analysis and the requirement of validation of differentially expressed genes identified by microarray analysis by the more sensitive qRT-PCR analysis (Rajeevan et al., 2001). The mRNA expression of IL-6 was significantly upregulated in Strep. uberis-infected tissue. There are no previous reports of IL-6 in association with Strep. uberis mastitis, but previous studies have shown an increase in IL-6 mRNA expression in milk somatic cells of dairy cows experimentally challenged with either E. coli or Staph. aureus (Lee et al., 2006).

The identification of genes that are upregulated in response to infection could have potential as candidate markers for the early detection of mastitis. However, due to the use of whole tissue in the microarray experiment, the identification of the immune response elicited by the bMEC was undetermined. Mastitis is associated with infiltration of the mammary tissue by neutrophils, macrophages, and lymphocytes. These, together with a range of different cytokines, chemokines, and additional cellular defense mechanisms, play a pivotal role in the elimination of invading bacteria. However, the recruitment of these cells into the mammary gland results in changes to the cellular composition of the mammary tissue. This has to be considered when attributing changes in gene expression in the mammary 


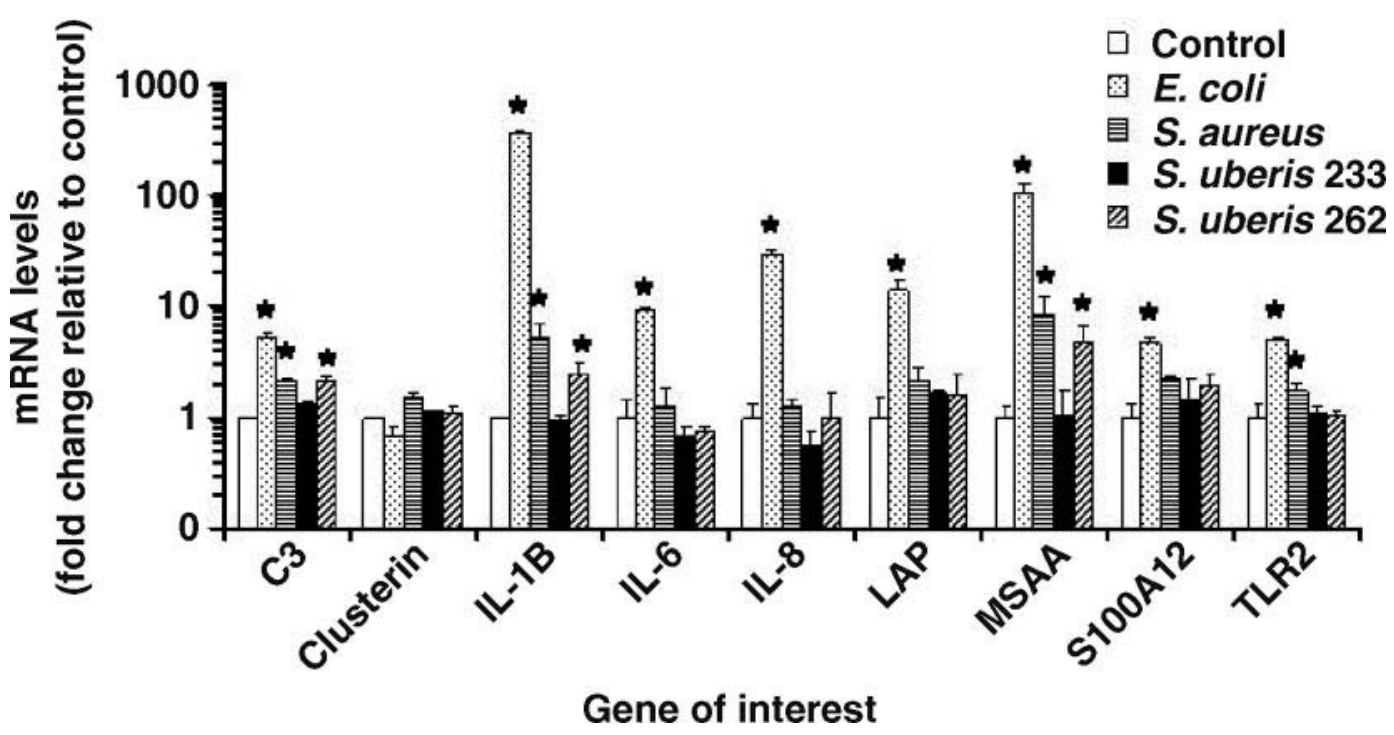

Figure 2. Quantitative PCR analysis of immune-associated genes showing the fold change in expression after incubation of primary mammary epithelial cells with PBS alone (control) or PBS with strains of heat-killed Escherichia coli, Staphylococcus aureus, Streptococcus uberis 233, or $S$. uberis $262(* P<0.05)$. Error bars denote SEM. C3 = complement component 3; LAP = lingual antimicrobial peptide; MSAA = serum amyloid A3; S100A12 = calgranulin C; TLR2 = toll-like receptor 2.

gland after mastitis. Recent studies have demonstrated that bMEC also play an important role in the immune defense against invading pathogens (Pareek et al., 2005; Strandberg et al., 2005; Zheng et al., 2006). Therefore, the immune response of primary bMEC to different mastitis pathogens was investigated. Heat-killed bacteria were added to primary mammary epithelial cells at a concentration of $10^{9} \mathrm{cfu} / \mathrm{mL}$. This concentration was chosen by measuring the expression of LAP mRNA after incubations with serial dilutions of $E$. coli (data not shown). This is a greater concentration than the typical bacterial concentration observed in vivo, which ranges from 10,000 to 1,000,000 cfu/mL (Kornalijnslijper et al., 2003; Rambeaud et al., 2003; Middleton et al., 2004). A 12-h incubation of the epithelial cells with heat-killed Strep. uberis 233 resulted in no significant increase in the expression of any of the 9 immunerelated genes investigated by qRT-PCR. In contrast, $E$. coli induced a significant increase in the transcript level for 8 of 9 immune-related genes. Furthermore, incubation with Staph. aureus and the encapsulated Strep. uberis 262 also induced an increase in expression of some of the immune-related genes (IL-1 $\beta$, C3, SAA3, and TLR2). Previous studies using bMEC observed that Strep. uberis at the same concentrations as E. coli and Staph. aureus did not increase the mRNA expression of measured cytokines and chemokines in primary bMEC (Wellnitz et al., 2006). Interestingly, not only do different bacteria elicit a different immune response as discussed earlier, but our results indicate that different strains of Strep. uberis also may elicit different immune responses by epithelial cells and one contributing factor may be the hyaluronic acid capsule. Support for this has been found in studies of different strains of Streptococcus suis, in which capsule expression appeared to be important for the activation of several proinflammatory cytokines in a whole blood culture system (Segura et al., 2006). However, further studies would be required to investigate the effect of the Strep. uberis hyaluronic capsule on epithelial-derived immune components in primary mammary epithelial cell culture. Numerous studies have also highlighted differences in the expression of immune factors being dependent on the infecting pathogen (Bannerman et al., 2004a,b; Strandberg et al., 2005). Although Strep. uberis 233 was able to cause clinical mastitis after infusion into mammary quarters of dairy cows, this strain did not induce the expression of any of the selected proinflammatory cytokines and other immune-related components in primary bMEC. Yet, previous studies have demonstrated the expression and localization of immune-related genes to bMEC (Goldammer et al., 2004; Swanson et al., 2004). These results, together with other studies (Wellnitz and Kerr, 2004; Wellnitz et al., 2006), indicate that the expression of epithelium-derived immune components may not be initiated by Strep. uberis 233 but by the immunemodulatory components of other immune cells in the mammary gland.

\section{CONCLUSIONS}

The microarray analyses described in this study demonstrated the complex physiological and cellular processes that occur in the bovine mammary gland 
after a Strep. uberis infection. Furthermore, changes in immune-related gene expression by mammary epithelial cells appear to be pathogen-specific. Together these results highlight the complexity of the immune response to an infecting pathogen and indicate that a coordinated response exists between the resident, recruited, and inducible immune factors.

\section{REFERENCES}

Altschul, S. F., W. Gish, W. Miller, E. W. Myers, and D. J. Lipman 1990. Basic local alignment search tool. J. Mol. Biol. 215:403410

Baird, D., P. Johnstone, and T. Wilson. 2004. Normalization of microarray data using a spatial mixed model analysis which includes splines. Bioinformatics 20:3196-3205.

Bannerman, D. D., M. J. Paape, J. P. Goff, K. Kimura, J. D. Lippolis, and J. C. Hope. 2004a. Innate immune response to intramammary infection with Serratia marcescens and Streptococcus uberis. Vet. Res. 35:681-700.

Bannerman, D. D., M. J. Paape, J. W. Lee, X. Zhao, J. C. Hope, and P. Rainard. 2004b. Escherichia coli and Staphylococcus aureus elicit differential innate immune responses following intramammary infection. Clin. Diagn. Lab. Immunol. 11:463-472.

Bayles, K. W., C. A. Wesson, L. E. Liou, L. K. Fox, G. A. Bohach, and W. R. Trumble. 1998. Intracellular Staphylococcus aureus escapes the endosome and induces apoptosis in epithelial cells. Infect. Immun. 66:336-342.

Blosser, T. H. 1979. Economic losses from and the national research program on mastitis in the United States. J. Dairy Sci. 62:119 127.

Capuco, A. V., S. E. Ellis, S. A. Hale, E. Long, R. A. Erdman, X Zhao, and M. J. Paape. 2003. Lactation persistency: Insights from mammary cell proliferation studies. J. Anim. Sci. 81(Suppl. 3):18-31.

Chapman, R. S., P. C. Lourenco, E. Tonner, D. J. Flint, S. Selbert, K. Takeda, S. Akira, A. R. Clarke, and C. J. Watson. 1999 Suppression of epithelial apoptosis and delayed mammary gland involution in mice with a conditional knockout of Stat3. Genes Dev. 13:2604-2616.

Cullen, G. A. 1966. The ecology of Streptococcus uberis. Br. Vet. J. 122:333-339.

DeGraves, F. J., and J. Fetrow. 1993. Economics of mastitis and mastitis control. Vet. Clin. North Am. Food Anim. Pract. 9:421434.

Dennis, G., B. T. Sherman, D. A. Hosack, J. Yang, M. W. Baseler, H. Clifford Lane, and R. A. Lempicki. 2003. DAVID: Database for Annotation, Visualization, and Integrated Discovery. Genome Biol. 4:3.

Goldammer, T., H. Zerbe, A. Molenaar, H. J. Schuberth, R. M. Brunner, S. R. Kata, and H. M. Seyfert. 2004. Mastitis increases mammary mRNA abundance of $\beta$-defensin 5 , toll-like-receptor 2 (TLR2), and TLR4 but not TLR9 in cattle. Clin. Diagn. Lab. Immunol. 11:174-185.

Hillerton, J. E., M. F. Shearn, R. M. Teverson, S. Langridge, and J. M. Booth. 1993. Effect of pre-milking teat dipping on clinical mastitis on dairy farms in England. J. Dairy Res. 60:31-41.

Huang, X., and A. Madan. 1999. CAP3: A DNA sequence assembly program. Genome Res. 9:868-877.

Humphreys, R. C., B. Bierie, L. Zhao, R. Raz, D. Levy, and L. Hennighausen. 2002. Deletion of Stat3 blocks mammary gland involution and extends functional competence of the secretory epithelium in the absence of lactogenic stimuli. Endocrinology 143:3641-3650.

Jain, N. C. 1979. Common mammary pathogens and factors in infection and mastitis. J. Dairy Sci. 62:128-134.

Khan, I. U., A. A. Hassan, A. Abdulmawjood, C. Lammler, W. Wolter, and M. Zschock. 2003. Identification and epidemiological characterization of Streptococcus uberis isolated from bovine mastitis using conventional and molecular methods. J. Vet. Sci. $4: 213-224$.

Kornalijnslijper, J. E., T. van Werven, A. J. Daemen, J. van den Broek, T. A. Niewold, V. P. Rutten, and E. N. Noordhuizen-Stassen. 2003. In vitro growth of mastitis-inducing Escherichia coli in milk and milk fractions of dairy cows. Vet. Microbiol. 91:125-134.

Lacy-Hulbert, S. J., R. T. Cursons, M. G. Lopez-Benavides, J. H. Williamson, E. L. Summers, S. M. Pryor, and M. W. Woolford. 2005. Isolation of Streptococcus uberis from different sites of the dairy cow. Pages 635-641 in Mastitis in Dairy Production: Current Knowledge and Future Solutions. H. Hogeveen, ed. Wageningen Academic Publishers, Wageningen, the Netherlands.

Lee, J. W., D. D. Bannerman, M. J. Paape, M. K. Huang, and X. Zhao. 2006. Characterization of cytokine expression in milk somatic cells during intramammary infections with Escherichia coli or Staphylococcus aureus by real-time PCR. Vet. Res. 37:219-229.

Leigh, J. A. 1999. Streptococcus uberis: A permanent barrier to the control of bovine mastitis? Vet. J. 157:225-238.

Long, E., A. V. Capuco, D. L. Wood, T. Sonstegard, G. Tomita, M. J. Paape, and X. Zhao. 2001. Escherichia coli induces apoptosis and proliferation of mammary cells. Cell Death Differ. 8:808-816.

McDougall, S. 2002. Bovine mastitis: Epidemiology, treatment and control. N. Z. Vet. J. 50(Suppl):81-84.

Middleton, J. R., C. D. Luby, L. Viera, J. W. Tyler, and S. Casteel 2004. Short communication: Influence of Staphylococcus aureus intramammary infection on serum copper, zinc, and iron concentrations. J. Dairy Sci. 87:976-979.

Milner, P., K. L. Page, and J. E. Hillerton. 1997. The effects of early antibiotic treatment following diagnosis of mastitis detected by a change in the electrical conductivity of milk. J. Dairy Sci. 80:859863.

Molenaar, A., G. Rajan, K. Stelwagen, M. Grigor, and S. Davis. 2000. A serum amyloid protein homologue is expressed by the mammary gland. N. Z. Med. J. 10:85. (Abstr.)

Paape, M. J., D. D. Bannerman, X. Zhao, and J. W. Lee. 2003. The bovine neutrophil: Structure and function in blood and milk. Vet. Res. 34:597-627.

Paape, M. J., K. Shafer-Weaver, A. V. Capuco, K. Van Oostveldt, and C. Burvenich. 2000. Immune surveillance of mammary tissue by phagocytic cells. Adv. Exp. Med. Biol. 480:259-277.

Pareek, R., O. Wellnitz, R. Van Dorp, J. Burton, and D. Kerr 2005. Immunorelevant gene expression in LPS-challenged bovine mammary epithelial cells. J. Appl. Genet. 46:171-177.

Pedersen, L. H., B. Aalbaek, C. M. Rontved, K. L. Ingvartsen, N S. Sorensen, P. M. Heegaard, and H. E. Jensen. 2003. Early pathogenesis and inflammatory response in experimental bovine mastitis due to Streptococcus uberis. J. Comp. Pathol. 128:156164.

Phillips, I., M. Casewell, T. Cox, B. DeGroot, C. Friis, R. Jones, C. Nightingale, R. Preston, and J. Waddell. 2004. Does the use of antibiotics in food animals pose a risk to human health? A critical review of published data. J. Antimicrob. Chemother. 53:28-52.

Rainard, P., and C. Riollet. 2006. Innate immunity of the bovine mammary gland. Vet. Res. 37:369-400.

Rajeevan, M. S., S. D. Vernon, N. Taysavang, and E. R. Unger. 2001 Validation of array-based gene expression profiles by real-time (kinetic) RT-PCR. J. Mol. Diagn. 3:26-31.

Rambeaud, M., R. A. Almeida, G. M. Pighetti, and S. P. Oliver. 2003 Dynamics of leukocytes and cytokines during experimentally induced Streptococcus uberis mastitis. Vet. Immunol. Immunopathol. 96:193-205.

Rozen, S., and H. Skaletsky 2000. Primer3 on the WWW for general users and for biologist programmers. Pages 365-386 in Bioinformatics Methods and Protocols: Methods in Molecular Biology. S. Krawetz and S. Misener, ed. Humana Press, Totowa, NJ.

Schena, M., D. Shalon, R. W. Davis, and P. O. Brown. 1995 Quantitative monitoring of gene expression patterns with a complementary DNA microarray. Science 270:467-470. 
Schroder, N. W., S. Morath, C. Alexander, L. Hamann, T. Hartung, U. Zahringer, U. B. Gobel, J. R. Weber, and R. R. Schumann. 2003. Lipoteichoic acid (LTA) of Streptococcus pneumoniae and Staphylococcus aureus activates immune cells via Toll-like receptor (TLR)-2, lipopolysaccharide-binding protein (LBP), and CD14, whereas TLR-4 and MD-2 are not involved. J. Biol. Chem. 278:15587-15594.

Segura, M., G. Vanier, D. Al-Numani, S. Lacouture, M. Olivier, and M. Gottschalk. 2006. Proinflammatory cytokine and chemokine modulation by Streptococcus suis in a whole-blood culture system. FEMS Immunol. Med. Microbiol. 47:92-106.

Shalon, D., S. J. Smith, and P. O. Brown. 1996. A DNA microarray system for analyzing complex DNA samples using two-color fluorescent probe hybridization. Genome Res. 6:639-645.

Singh, K., S. R. Davis, J. Dobson, A. Molenaar, T. T. Wheeler, C. G. Prosser, V. C. Farr, K. Oden, K. M. Swanson, C. V. C. Phyn, D. L. Hyndman, T. Wilson, H. V. Henderson, and K. Stelwagen. 2008. cDNA microarray analysis reveals antioxidant and immune genes are up-regulated during involution of the bovine mammary gland. J. Dairy Sci. 91:2236-2246.

Singh, K., M. Prewitz, J. Dobson, C. Phyn, A. Molenaar, V. Farr, S. Davis, and K. Stelwagen. 2006. Intramammary Streptococcus uberis infection induces innate immune responses and apoptosis in bovine mammary epithelial cells. In Proc. 8th Int. Workshop BOLFA, Brazil. (Abstr.)

Sordillo, L. M., K. Shafer-Weaver, and D. DeRosa. 1997. Immunobiology of the mammary gland. J. Dairy Sci. 80:1851-1865.

Stelwagen, K., and S. J. Lacy-Hulbert. 1996. Effect of milking frequency on milk somatic cell count characteristics and mammary secretory cell damage in cows. Am. J. Vet. Res. 57:902-905.

Stockum, C., B. J. Haigh, H. H. D. Meyer, R. M. Bruckmaier, T. T. Wheeler, and K. Singh. 2008. Expression of innate immune response genes in mammary epithelia following stimulation with lipopolysaccharide or Escherichia coli. Brief Communication. Proc. N. Z. Soc. Anim. Prod. 68:31-32
Strandberg, Y., C. Gray, T. Vuocolo, L. Donaldson, M. Broadway, and R. Tellam. 2005. Lipopolysaccharide and lipoteichoic acid induce different innate immune responses in bovine mammary epithelial cells. Cytokine 31:72-86.

Swanson, K., S. Gorodetsky, L. Good, S. Davis, D. Musgrave, K. Stelwagen, V. Farr, and A. Molenaar. 2004. Expression of a $\beta$-defensin mRNA, lingual antimicrobial peptide, in bovine mammary epithelial tissue is induced by mastitis. Infect. Immun. 72:7311-7314.

Teuber, M. 2001. Veterinary use and antibiotic resistance. Curr. Opin. Microbiol. 4:493-499.

Viard, I., P. Wehrli, L. Jornot, R. Bullani, J. L. Vechietti, J. A. Schifferli, J. Tschopp, and L. E. French. 1999. Clusterin gene expression mediates resistance to apoptotic cell death induced by heat shock and oxidative stress. J. Invest. Dermatol. 112:290-296.

Ward, P. A. 1983. Role of toxic oxygen products from phagocytic cells in tissue injury. Adv. Shock Res. 10:27-34.

Weinrauch, Y., and A. Zychlinsky. 1999. The induction of apoptosis by bacterial pathogens. Annu. Rev. Microbiol. 53:155-187.

Wellnitz, O., and D. E. Kerr. 2004. Cryopreserved bovine mammary cells to model epithelial response to infection. Vet. Immunol. Immunopathol. 101:191-202.

Wellnitz, O., P. Reith, S. C. Haas, and H. H. D. Meyer. 2006. Immune relevant gene expression of mammary epithelial cells and their influence on leukocyte chemotaxis in response to different mastitis pathogens. Vet. Med. (Praha) 51:125-132.

Zhang, H., J. K. Kim, C. A. Edwards, Z. Xu, R. Taichman, and C. Y. Wang. 2005. Clusterin inhibits apoptosis by interacting with activated Bax. Nat. Cell Biol. 7:909-915.

Zheng, J., A. D. Watson, and D. E. Kerr. 2006. Genome-wide expression analysis of lipopolysaccharide-induced mastitis in a mouse model. Infect. Immun. 74:1907-1915. 